\title{
Greater openness urged over nuclear waste storage plans
}

London. Britain's Royal Society has urged the company drawing up plans for the country's first depository for radioactive waste to include provisions for storing high-level waste - even though the company itself, UK Nirex Ltd, fears that any such proposal could inflame public opposition.

It has also urged greater openness in the distribution of the company's scientific reports, saying that it was "forcibly struck" by the way some of these had been protected from public scrutiny.

The recommendations come in a report published last week by a six-member committee set up by the society at Nirex's request. The group was chaired by Sir Alan Muir Wood, a prominent consultant engineer, to study the scientific aspects of the company's plans for a nuclear waste depository close to the Sellafield reprocessing plant in Cumbria. Nirex's plans to store low-level waste and intermediate-level waste some 650 metres underground have caused a storm of protest, in particular because of concern that water contaminated with radionuclides could rise to the surface (see Nature 369, 698; 1994).

The report says that the Sellafield area is hydrogeologically complex, with most groundwater flow occurring through fractured rocks. The task of assessing where water from the potential repository zone (PRZ) flows now, and in the long-term future, is the key to predicting how the sealed repository would perform. "If one had simply a set of geological factors to choose from, it is unlikely that Sellafield would be the first choice," Wood said last week. But, he added, "it doesn't have to be the best site, it has to fulfil certain criteria".

The study group's report also concludes that the identification of the PRZ "appears to have been somewhat premature", and that it should be extended deeper and to the west where conditions appear more stable.

The report points out that "currently available preliminary information indicates that the high salinity of the groundwater and longer flow paths may result in lower levels of radioactivity moving towards the ground's surface". If this were the case, such a depository could also be used for high-level waste. At present, Nirex has no responsibility for disposing of such waste; but the society group points out that there is not even a research programme in the United Kingdom for its disposal.

While praising the quality of much of the work undertaken and commissioned by Nirex, the group says it felt that the "innovative and complex nature" of the work needed to understand the structure of the area, and the need for peer review, meant that the
Nirex timetable was too optimistic. Under this timetable, the first deposits of waste would take place in 2010 .

Wood also advised Nirex to be as "open as possible" in discussing and publishing its scientific data, enabling wide peer review and the selection of the best site by a "highly iterative interaction" between the scientists and the design engineers.

But the Royal Society backed Nirex's plans for a rock characterization facility (RCF), and said that such a 'rock laboratory' should be built "as soon as is practicable", provided sufficient information was obtained before the hydrogeological regime of the area is disturbed by the RCF.

Nirex applied to Cumbria County Council for planning permission for the RCF in July, and council representatives immediately wrote to the Secretary of State for the Environment asking for the application to be

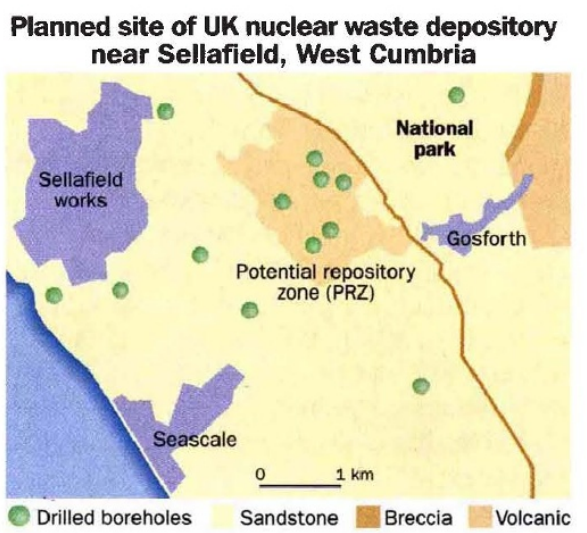

'called-in' for a public inquiry. The council is concerned about the way that Sellafield was chosen from an original list of candidate sites and the lack of sufficient information on findings so far.

In a separate report, the Royal Society calls on the government to develop national policies on both energy generation and the civilian use of plutonium. Its comments come in a response to a consultation document from the DoE on radioactive waste management, which describes issues raised by existing and future waste as "a problem that faces all citizens, whatever their views about the desirability of nuclear power".

Sir Francis Graham-Smith, physical secretary and vice-president of the Royal Society, called on the government to reconsider the possibilities for disposing radioactive waste in the ocean, even though this is at present ruled out by international law. "There are obvious attractions of ocean disposal, and we should keep looking at the science of that," said Graham-Smith. Maggie Verrall

\section{Row over new job losses at German microscope factory}

Munich. Carl Zeiss, the German company that supplies about a quarter of the world's microscope market, has been told by the local government in Jena, where its east German factory is based, that plans to cut 3,000 jobs in 1996 violate a previous agreement not to make further cutbacks.

The proposed cuts are to be spread throughout the company. But Jena would lose 600 of its 2,000 jobs in the plan, a much higher percentage than the company's other locations. Union officials fear that even more cuts may be on the way, and that the Jena branch may eventually be closed.

Zeiss was founded in Jena in the late nineteenth century. But at the end of the Second World War, when Germany was occupied by the Allied Forces, US troops led a core group of scientists out of eastern Germany to start a new Zeiss company in Oberkochen, Baden-Württemberg.

After reunification, Zeiss Oberkochen merged with the fine optics and mechanics sections of its Jena predecessor and competitor. Zeiss now owns 51 per cent of the company and the remaining 49 per cent is owned by the Land of Thüringen, where Jena is located.

But the merger precipitated a financial crisis, prompting Zeiss to reduce its workforce to $16,000,85$ per cent of whom work in Germany. The recent announcement of additional job losses has provoked strikes in both Oberkochen and Jena.

In January, Thüringen, where Zeiss is an important employer, signed an agreement with Zeiss for staff cuts of 800 by 1996 . Hans Kaiser, a spokesman for Thüringen, claims that this agreement meant that no additional cuts would be enforced.

But Berndt Räbel, a Zeiss spokesman, says the agreement allowed for additional cutbacks if the company encountered special financial problems. "Jena will remain an integral and vital part of Zeiss," he says, adding that research and development will continue at Oberkochen and Jena.

In an attempt to improve the strained relationship between Zeiss management and the east Germans, the company is reorganizing its four-member board. Peter Grassmann, now a board member of Siemens and widely recognized as an effective negotiator, has been appointed to the board and will also join Zeiss management in Jena.

Kaiser believes that Grassman's more direct style will help to diffuse tensions and give a fresh impetus to negotiations. Roland Hamm of IG Metal, the trade union that represents Zeiss's employees, says that the appointment of a new board representative can be seen as a first conciliatory step by the management.

Toni Feder 